\title{
Massage for Eid Travelers in 2019
}

\author{
Danang Ari Santosoํ, Wawan Setiawan², Bayu Septa M.T³, Mislan', Arya T Candra ${ }^{5}$ \\ 1,2,3,4,5 Health and Recreation Physical Education Study Program, Banyuwangi PGRI University \\ Email: danangarisantoso@gmail.com¹,wawan11setiawan11@gmail.com², bayusepta7@gmail.com³, \\ mislanmpd680@gmail.com ${ }^{4}$, aryacandra0189@gmail.com 5
}

\begin{abstract}
Homecoming activities that occur each approaching Eid certainly make travelers feel exhausted on the way to their hometown. So with that it requires activities that help travelers. In this case we provide a place to rest for travelers and provide free massage for travelers. Massage comes from the French word "masser" which means rubbing or from the Arabic word "mash" which means to press it gently or from the Greek word "massien" which means to massage or wrap. With the provision of massage it is expected that travelers can relax and make the body fit again. Based on the above problems, we need a place of rest for travelers who drive motorized vehicles and volunteers who are able to reduce driver fatigue by giving free massage to the travelers. With this done, it is expected that the smoothness and safety of motorists who make homecoming in 2019 can be maintained until they are in their respective hometowns. The target of this community service activity is travelers in 2019 who pass through Banyuwangi City. The preparatory stages include location survey, after that coordinate with the campus to hold campus room loan licensing as a place of rest and massage place for the homecomers. In addition, we are socializing to the public that there will be a free massage at Campus C, Uniba Banyuwangi. Providing all the facilities of massages, such as mattresses, olive oil and towels. The implementation phase is carried out May 18-19, 2019. The homecomers are recorded by filling in attendance and biodata. Travelers come into the room to rest and are given massage treatment. Based on the results of community service activities that have been carried out, the people who have been going home in 2019 are happy and are greatly helped by the location of free rest and massage. The resting place is very helpful for travelers to see a long time in travel and the long distance traveled by the travelers. For free massage activities also make travelers feel more comfortable and more fit to continue their homecoming journey to their hometown.
\end{abstract}

Keyword: Going home, free massase

\section{Pendahuluan}

Mudik adalah hal yang selalu hadir disetiap tahun dibulan ramadhan menjelang hari raya idul fitri. Sebagian masyarakat yang bekerja dikota tentunya akan pulang ke kampung halaman untuk berkumpul serta bersilaturahim bersama keluarga. Karena moment ini dirayakan oleh sebagian besar masyarakat dan kebanyakan masyarakat yang bekerja dikota adalah orang desa yang tentunya mempunyai jarak yang cukup jauh setiap tahun banyak kejadian kecelakaan yang terjadi disaat mudik. Salah satu faktor terjadinya kecelakaan tersebut karena keletihan oleh si pengendara karena jarak yang ditempuh sangat jauh.

Mudik dapat diartikan sebagai "pulang kampung" walau secara harafiah sebenar- nya berasal dari kata "udik = desa", sehingga arti mudik dapat diterjemahkan sebagai "pulang kampung" yang selalu dilakukan masyarakat Indonesia menjelang perayaan Idul Fitri tiba (KKBI, 2010). Umumnya mudik 
GANDRUNG: Jurnal Pengabdian Kepada Masyarakat ISSN: 0000-0000 (Online)

ISSN: 0000-0000 (Print)

lebaran dilakukan oleh segenap umat beragama Islam yang berada diperantauan atau bertempat tinggal jauh dari kampung halaman mereka. Kebiasa an ini dilakukan pada 7 (tujuh) hari sebelum lebaran hingga 7 (tujuh) hari sesudah hari raya tersebut. Jangka waktu kepulangan sampai kembali ketempat asal antara orang perorang sa ngat berbeda tergantung pada masa liburan yang diberikan oleh majikan atau tempat mere ka bekerja di kota. Jangka waktu seminggu sebelum hingga seminggu sesudahnya itu ada lah waktu terlama yang dipergunakan oleh mereka yang melakukan perjalanan mudik le baran tersebut.

Dapat dikatakan bahwa mudik lebaran bagi masyarakat Indonesia merupakan satu ibadah atau ritual tahunan yang tak boleh dilanggar dan hal ini sama sekali dapat dikata kan tidak mengenal status sosial - ekonomi maupun derajat kehidupan seperti kaya atau miskin, mampu atau kurang mampu, sehingga memang ritual tahunan ini selalu marak dan mungkin melanggar aturan serta penghalang apapun yang ada bila keinginan untuk mudik lebaran sudah menjadi prioritas utama pada saat menghadapi lebaran atau hari ra ya Idul Fitri. Secara budaya mungkin kegiatan mudik lebaran identik dengan kemenangan yang diperoleh umat manusia terutama yang beragama Islam setelah 1 (satu) bulan lamanya menunaikan kewajiban agama yaitu melaksanakan ibadah puasa, sehingga salah satu wujud kemenangan tersebut harus dan akan diperingati bersama keluarga di daerah asal atau kampung halaman yang terletak terkadanga sangat jauh dari tempat kedatangan (place of destination). Menurut teori migrasi, perpindahan sponta dan bersifat sementara ini dapat di kategorikan sebagai "temporarily migration" karena setiap migran hanya berniat untuk bepergian atau pindah dari tempat mereka ke suatu tempat lain dalam waktu yang relatif singkat tanpa niatan untuk menetap (Mantra, 2011).

Kegiatan mudik yang terjadi setiap mendekati lebaran tersebut tentunya membuat pemudik merasa kelelahan dalam perjalanan ke kampung halaman. Sehingga dengan hal tersebut memerlukan kegiatan yang membantu pemudik. Dalam hal ini kami memberikan tempat untuk beristirahat bagi pemudik serta pemberian masase gratis bagi pemudik. Massage berasal dari bahasa Perancis "masser" yang berarti menggosok atau dari kata Arab "mash" yang berarti menekan dengan lembut atau dari kata Yunani "massien" yang berarti memijat atau melulut (Widhiyanti, 2017). Dengan pemberian masase tersebut diharapkan pemudik mampu rileks dan membuat tubuh kembali prima.

\section{Metode}

1. Khalayak Sasaran

Sasaran kegiatan pengabdian ini adalah pemudik di tahun 2019 yang melewati Kota Banyuwangi. 
GANDRUNG: Jurnal Pengabdian Kepada Masyarakat ISSN: 0000-0000 (Online)

ISSN: 0000-0000 (Print)

\section{Tahapan Persiapan}

Tahapan persiapan meliputi survei lokasi, setelah itu berkoordinasi dengan pihak kampus untuk mengadakan perijinan peminjaman ruangan kampus sebagai tempat istirahat dan tempat masase para pemudik.Selain itu kami melakukan sosialisasi kepada masyarakat bahwa akan diadakan masase gratis di Kampus C Uniba Banyuwangi. Menyediakan segala sarana prasarana masase, seperti matras, minyak zaitun serta handuk.

\section{Tahapan Pelaksanaan}

a. Tahap pelaksanaan dilakukan 18-19 Mei 2019.

b. Pemudik di data dengan mengisi absensi dan biodata.

c. Pemudik masuk ke ruangan untuk istirahat dan di berikan perlakuan masase.

\section{Tahap Evaluasi Akhir}

Pada tahap ini dilakukan pembuatan laporan tahap akhir, yang berisi laporan hasil kegiatan masase gratis sekaligus saran dan kritik yang berkaitan dengan pelaksanaan program.

\section{Hasil dan Diskusi}

Kegiatan masase gratis ini dimulai tanggal 18-19 Mei 2019, pukul 08.00- 16.00 wita berlokasi di kampus C Universitas PGRI Banyuwangi. Pelaksanaan awal peserta masase mengisi absen terlebih dahulu setelah itu mengantri untuk di masase diruang masase. Pelaksanaan masase kurang lebih 15 menit untuk 1 orang pemudik. Adapun bagian tubuh yang dimasase adalah bagian tangan dan kaki. Karena sebagian besar bagi para pemudik bagian itu yang paling banyak mengalami kelelahan. Setelah melakukan masase pemudik diperbolehkan untuk istirahat lebih lama sampai kondisinya kembali prima untuk kembali melanjutkan perjalanan.

Di hari pertama dalam kegiatan masase gratis ini terdapat 42 pemudik yang berpartisipasi dan di hari kedua sebanyak 34 orang pemudik yang memanfaatkan kegiatan masase gratis tersebut. Dengan demikian antusias dari pemudik lebaran tahun 2019 cukup baik terhadap kegiatan masase gratis di tahun 2019. 


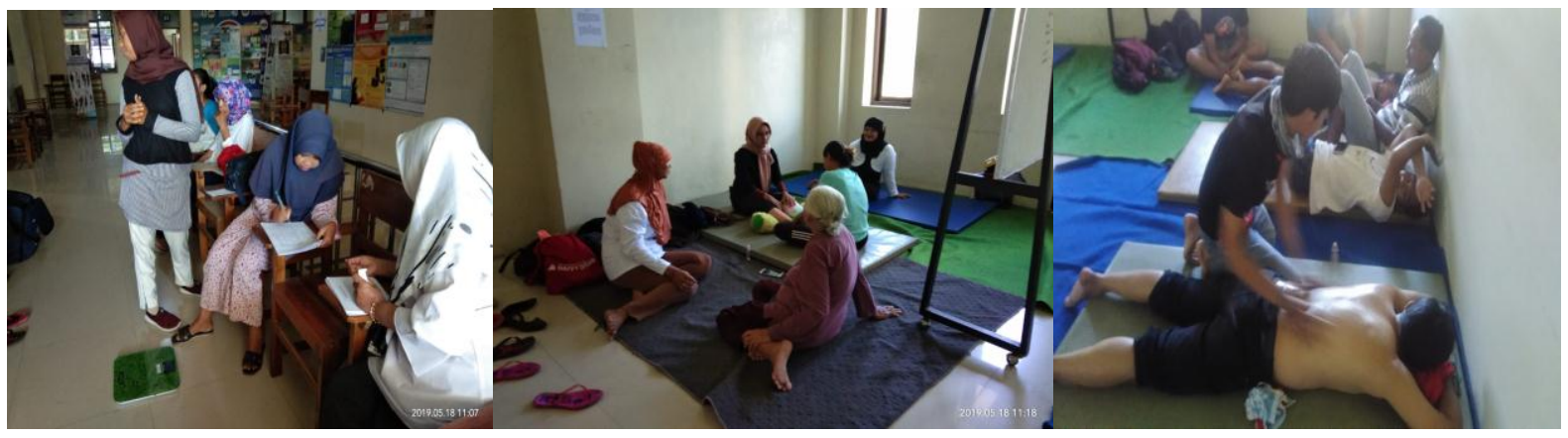

Gambar 1. Kegiatan Massase Gratis

Berdasarkan hasil tersebut maka dapat disimpulkan partisipasi dari masyarakat yang mudik di tahun 2019 cukup baik terhadap kegiatan masase gratis tersebut.

\section{Kesimpulan}

Refleksi hasil pendampingan dan rekomendasi. Berdasarkan hasil kegiatan pengabdian yang sudah dilaksanakan, masyarakat yang melaksanakan mudik di tahun 2019 merasa senang dan sangat terbantu dengan adanya lokasi untuk beristirahat dan masase gratis. Tempat beistirahat tersebut sangat membantu pemudik melihat waktu yang lama dalam perjalanan dan jarak yang jauh yang ditempuh oleh pemudik tersebut. Untuk kegiatan masase gratis juga membuat pemudik merasa nyaman dan lebih fit untuk melanjutkan perjalanan mudik ke kampong halaman mereka.

Kegiatan masase gratis tersebut sangat penting dilaksanakan sebagai kegiatan yang sangat membantu bagi pemudik, hal ini dapat dimaksimalkan lagi dengan lebih gencar dalam pemberian sosialisasi serta informasi kepada masyarakat luas terutama pemudik. Yang terpenting dari kegiatan tersebut secara tidak langsung kegiatan mudik di tahun 2019 berjalan aman serta lancar sampai ke kampong halaman masing-masing.

\section{Daftar Referensi}

Kamus Besar Bahasa Indonesia. Diperoleh 1 mei 2019. dari https://kbbi.web.id/mudik

Soebyakto, B. Mudik Lebaran. Konomi pembangunan Journal of Economic \& Development HAL: 61 67. 2011

Widhiyanti. Teknik Massage Effleurage Pada Ekstremitas Inferior Sebagai Pemulihan Pasif Dalam Meningkatkan Kelincahan Jurnal Pendidikan Kesehatan Rekreasi Volume 1: Hal. 9 - 17. 2017. 